Ferencz Árpád

\title{
A kisgazdaságok jövedelemtermelő képességének lehetőségei
}

\author{
Árpád Ferencz \\ The Opportunities for the Profit Producing Ability of Subsistence Farms
}

\begin{abstract}
Összefoglalás
Az általunk készített modellben szabadföldi technológiával elöállított zöldségfajok jövedelemtermelö képességét mutatjuk be. Megvizsgáljuk az egymás után termeszthetó zöldségfajokat, amelyek egész évben munkát és bevételt adnának a termelöjének. Modellünkben kiszámításra kerülnek a szabadföldön termesztett zöldségkultúrák termesztési költségei (anyag, munkabér, közteher, gépi munka), a felmerülö szolgáltatás költségei. Az árbevétel vizsgálatánál meghatározzuk az egyes növények termésmennyiségét (pontosabban árumennyiségét). Vizsgáljuk az egyes idöszakokhoz tartozó értékesítési átlagárat, amelynél figyelembe vesszük a minőséget, az értékesítés irányát. Modellünkben kiszámítjuk, hogy az adott terület mekkora nettó jövedelmet eredményez az egyes fajok társítása esetén. Az egységnyi felület jövedelemtartalma pedig arra ad választ, hogy a vállalkozónak mekkora felületen kellene folytatni tevékenységét a maga- és családja eltartásához.

Kulcsszavak: kisgazdaság, eredményesség, eltartóképesség
\end{abstract}

Summary

In order to be able to prepare accurate calculations we had to determine the area and number of plants both in the case when the seeds were sown in the field and when they were in seedling transplants. The time requirements of the treated areas and also material used associated with the different modes of propagation varied. There are significant differences between the field and forcing technologies as for construction-related costs. The expense and cost calculations were based on the operation. The calculation includes the operating natural inputs (labour, material used), and are expressed in monetary value: the costs (wages, cost of materials). Costing does not count with the common charge, since the production process has not been completed yet. In this calculation the cost of labour is recognized. We calculated the area which can give enough profit to support the farmer and his family.

Keywords: subsistence farms, efficiency, breadwinning capacity

\section{BEVEZETÉS}

A Kecskeméti Főiskola Kertészeti Főiskolai Kara a régióban fontos szaktanácsadási szerepet tölt be. Az intézményben a régió mezőgazdasági vállalkozásai rendszeresen tájékozódhatnak a legújabb növénytermesztési, kertészeti termesztési, növényvédelmi, technológiai, agrárökonómiai szakmai ismeretekről. A gazdálkodókon kívül olyan, a munkaerőpiacról kiszorult emberek számára az öngondoskodás felé vezető utat próbálnak mutatni, amely révén egyrészt ezek az emberek megteremthetik részben önellátásukat, másrészt kiegészítő jövedelemhez juthatnak. 
Kutatásunknak két fő kimeneti területe van: egyrészt egy modell, amely összefoglalja azt a termesztéstechnológiát, amely optimális egy házkörüli kisegítő gazdaság létrehozásához és múködtetéséhez, másrészt ehhez kapcsolódó modellszámítások a termelés eredményességét mutatják be.

A Kecskeméti Főiskola Kertészeti Főiskolai Karán a gazdálkodókat segítő bemutatókert került kialakításra. Ez egyrészt a legfontosabb zöldségkultúrák technológiáját mutatják be, másrészt termesztésének piaci és agrárökonómiai értékelését modellszámításokon keresztül adnak szaktanácsot a gazdálkodóknak, az érdeklődő hallgatóknak és a leendő vállalkozóknak.

A Kertészeti Főiskolai Kar Bemutatókertjében kialakítottunk olyan területet, ahol szabadföldi és hajtatott zöldségkultúrákat előállító gazdaságot modellezünk. A modellben azt mutatjuk be, hogyan kell egymás után olyan növényeket termeszteni, amely egységnyi felületen a legnagyobb jövedelmet biztosítja. Kora, középkorai és másodvetemények modellezésében a saláta, gyökérzöldségek, paprikafajták, paradicsom, hüvelyesek vesznek részt az optimális és egy család által kezelhető felület megválasztásával. Ezek értékesítését úgy modellezzük, hogy az érési időpontjukra jellemző piaci átvételi árakkal számolunk. A költségkalkulációkat az egyszeres könyvelés szabályai szerint vizsgáljuk. Kiszámítjuk az egyes kultúrák jövedelemtartalmát és az eredményességi mutatóik alapján javaslatot teszünk azok termesztésére. A program új modell-farmgazdasági üzlet létrehozására ad példát, amely képviseli a legjobb termelési technológiát, az optimális és sikeres gazdasági méretet. A program hozzájárul egy olyan stratégiához a szinergiák időszakában, ami munkanélküli embereknek segít vidéki településeken abban, hogy jövedelemhez jussanak.

\section{ANYAG ÉS MÓDSZER}

\subsection{A modellgazdaság bemutatása}

A kutatást Kecskeméti Főiskola Kertészeti Főiskolai Kar Bemutatókertjében folytattuk szabadföldi és hajtatott körülmények között. Ennek célja volt olyan termesztéstechnológiák összeállítása, amely egyrészt lehetővé teszi a minél nagyobb arányú önellátást, másrészt kiegészítő jövedelmet biztosít, harmadrészt pedig, egy ember részmunkaidőben el tudja látni a múvelését. A termesztésre szóba jöhető fajok kiválasztása a két területen honos, ismert zöldségnövényekből történik, úgy hogy az áru előállítása február közepétől október végéig folyamatosan történjen. A zöldségfajok kiválasztása mellett a kutatás célja a megfelelő arányok, termesztési sorrendek, valamint a vegyszermentes megoldások kidolgozása is, a minél egészségesebb élelmiszerek elóállítása érdekében is. Az 1 . és 2 . táblázat az egymást követő termesztésbe vont kultúrák területi adatait mutatják be.

\section{1. táblázat: Az első szakaszban termesztett} szabadföldi kultúrák

\begin{tabular}{|l|l|}
\hline \multicolumn{1}{|c|}{ Növény } & \multicolumn{1}{|c|}{ Nettó felület } \\
\hline Zöldborsó ( 4 fajta) & $78 \mathrm{~m}^{2}$ \\
\hline Zöldbab (3 fajta) & $58,5 \mathrm{~m}^{2}$ \\
\hline Fejessaláta & $58 \mathrm{~m}^{2}$ \\
\hline Karalábé (2 fajta) & $39 \mathrm{~m}^{2}$ \\
\hline Retek (4 fajta) & $19,5 \mathrm{~m}^{2}$ \\
\hline Kelkáposzta (1 fajta) & $19,5 \mathrm{~m}^{2}$ \\
\hline Zeller (1 fajta) & $19,5 \mathrm{~m}^{2}$ \\
\hline Sárgarépa (1 fajta) & $10 \mathrm{~m}^{2}$ \\
\hline Petrezselyem (1 fajta) & $10 \mathrm{~m}^{2}$ \\
\hline Összesen: & $292,5 \mathrm{~m}^{2}$ \\
\hline
\end{tabular}

2. táblázat: A második szakaszban termesztett szabadföldi kultúrák

\begin{tabular}{|l|l|}
\hline \multicolumn{1}{|c|}{ Növény } & \multicolumn{1}{c|}{ Nettó felület } \\
\hline fejeskáposzta (1 fajta) & $58 \mathrm{~m}^{2}$ \\
\hline Kelkáposzta (1 fajta) & $59 \mathrm{~m}^{2}$ \\
\hline Karfiol (1fajta) & $20 \mathrm{~m}^{2}$ \\
\hline paprika (2 fajta) & $68 \mathrm{~m}^{2}$ \\
\hline paradicsom (2 fajta) & $48 \mathrm{~m}^{2}$ \\
\hline Zeller (1 fajta) & $19,5 \mathrm{~m}^{2}$ \\
\hline Sárgarépa (1 fajta) & $10 \mathrm{~m}^{2}$ \\
\hline Petrezselyem (1 fajta) & $10 \mathrm{~m}^{2}$ \\
\hline Összesen: & $292,5 \mathrm{~m}^{2}$ \\
\hline
\end{tabular}


3.2. Az agrárökonómiai számítások módszere A ráfordítások és a költségek a múveleti kalkulációra épülnek. A múveleti kalkuláció tartalmazza a naturális ráfordításokat (élőmunka-szükségelet, anyag felhasználás), valamint az ezek pénzben kifejezett értékét (anyagköltség, munkabér, közteher). A modellben a gazdálkodó munkabére az értékesítés után, bruttó jövedelem formájában keletkezik.

A pontos számítás érdekében külön-külön meg kellett határozni a magból vetett- és a palántával előállított növények területét és mennyiségét. Ez a kezelendő területek különböző időszükségletét és az eltérő szaporítási módhoz kapcsolódó anyagfelhasználást eredményezte.

$\mathrm{Az}$ anyagok ára minden esetben tartalmazza az Áfát, mivel a modellben a gazdálkodók nem lesznek Áfa körösök.
Az anyagok számításánál több olyan tényezőt nem vettünk számításba, amely akár részét képezheti a termesztésnek (pl. szerszámok, eszközök, stb.), azonban ezek egy megfelelő területtel rendelkező magánszemélynél mindennapi használatban vannak.

Ebben a kalkulációban a palántanevelési költséget beépítettük, de azt olyan egységáron, amelyen a gazdálkodó a palántákat készen megvásárolhatja, e költség ezért nem torzít.

A termesztéstechnológia végén lehet majd a múveleti költségekből meghatározni az egyes költségnemeket (anyag, munkabér, stb.) és az értékesítés után a bevételeket.

\section{EREDMÉNYEK}

A szabadföldi kultúrák ökonómiai értékelését a 3.-4. táblázatok foglalják össze.

3. táblázat: A szabadföldi zöldségnövények árbevételének, költségeinek alakulása

\begin{tabular}{|c|c|c|c|c|}
\hline Növény & $\begin{array}{c}\text { Termés } \\
\text { mennyiség (kg) }\end{array}$ & Árbevétel (Ft) & Költség (Ft) & Jövedelem (Ft) \\
\hline Korai kelkáposzta & 78 & 20377,5 & 17182 & 3195,5 \\
\hline Kései kelkáposzta & 156 & 47385 & 34852 & 12533 \\
\hline Fejeskáposzta & 390 & 64057,5 & 56714 & 7343,5 \\
\hline Saláta & 320 & 86850 & 54544 & 32306 \\
\hline Paradicsom & 377 & 95411,2 & 64739 & 30672,2 \\
\hline Fehérpaprika & 351 & 96886,5 & 86797 & 10089,5 \\
\hline Karfiol & 57 & 14620,5 & 10648,5 & 3972 \\
\hline Retek & 40 & 7020 & 6033,4 & 986,6 \\
\hline Zöldborsó & 195 & 84942 & 74482 & 10460 \\
\hline Zöldbab & 117 & 54545,4 & 42529 & 12016,4 \\
\hline Sárgarépa & 292,5 & 34433,1 & 19498 & 14935,1 \\
\hline Petrezselyem & 156 & 62309,5 & 15716 & 46593,5 \\
\hline Zeller & 121 & 30466,8 & 15202 & 15264,8 \\
\hline Karalábé & 85 & 48262,5 & 33648 & 14614,5 \\
\hline Összesen: & 2735,5 & 747567,5 & 532584,9 & 214982,6 \\
\hline \multicolumn{2}{|c|}{ Fajlagos érték (1 m2): } & 2491,9 & 1775,3 & 716,6 \\
\hline
\end{tabular}

A táblázatban eltérő jövelmet biztosító kultúrákat modelleztünk. A legmagasabb jövedelmet önmagában nem egy növény adja, hanem az egymás utáni termesztés optimális kombinációja. A termesztésnél azonban a terület folyamatos megmúvelését és a folymatos árbevételt is figyelembe kell venni, ezért az élőmunkaszükséglet vizsgálatára mindenképpen figyelemmel kell lenni. Ezt támasztja alá a 4 . táblázat, amelyben az élőmunka értéke, az eszközérték is bemutatásra kerül. 
Ökonómia, szervezés és marketing napjainkban

4. táblázat: A szabadföldi zöldségnövények árbevételének, költségeinek alakulása

\begin{tabular}{|c|l|r|r|r|}
\hline Ssz. & \multicolumn{1}{|c|}{ Növény } & $\begin{array}{c}\text { Élómunka- } \\
\text { szükséglet (óra) }\end{array}$ & $\begin{array}{c}\text { Élómunka érték } \\
\text { (Ft) }\end{array}$ & Eszközérték (Ft) \\
\hline 1. & Korai kelkáposzta & 12,9 & 6908,0 & 10274,0 \\
\hline 2. & Kései kelkáposzta & 25,25 & 14,303 & 34837,7 \\
\hline 3. & Fejeskáposzta & 48,11 & 27257 & 29457,0 \\
\hline 4. & Saláta & 40 & 22645 & 31899,0 \\
\hline 5. & Paradicsom & 42,2 & 23873 & 40866,0 \\
\hline 6. & Fehérpaprika & 48,2 & 30145 & 56652,0 \\
\hline 7. & Karfiol & 48,2 & 5994 & 4654,5 \\
\hline 8. & Retek & 5,5 & 3146 & 2887,4 \\
\hline 9. & Zöldborsó & 69,8 & 40181 & 34301,0 \\
\hline 10. & Zöldbab & 34,6 & 19618 & 22911,0 \\
\hline 11. & Sárgarépa & 15,1 & 11049 & 8449,0 \\
\hline 12. & Petrezselyem & 9,9 & 7167 & 8549,0 \\
\hline 13. & Zeller & 14,4 & 8155 & 7047,0 \\
\hline 14. & Karalábé & 25,8 & 14612 & 19036,0 \\
\hline Összesen: & & 439,96 & 220764,303 & 311820,597 \\
\hline & Fajlagos érték (1 m2): & 1,5 & 735,9 & 1039,4 \\
\hline
\end{tabular}

\section{KÖVETKEZTETÉSEK}

Vizsgálataink segítségével arra kaphatunk választ, hogy mekkora felületen kell gazdálkodni vagy hogy mekkora terménymennyiséget kell elérni a vállalkozó megélhetéséhez. Érdemes a jövedelmet munkaidőre levetíteni, mivel ez megadja az egységnyi munkaidő felhasználásával elérhető profitot. A modell bemutatja az egymás után termeszthető zöldségfajokat, amelyek egész évben munkát és bevételt adnának a termelőjének. Modellünkben azt is bemutatjuk, hogy az adott terület mekkora nettó jövedelmet eredményez az egyes fajok társítása esetén.

A modell azonban több problémát nem vizsgál, de nem is ez a cél. Nem vizsgálja pl. a likviditás kérdését, vagyis hogy az egyes hónapok jövedelemi hogyan befolyásolják a gazdálkodás fizetőképességét.

A gazdálkodó részére ez a modell egy kerettechnológiát bocsát rendelékezésére. Amennyiben a vállalkozó ezt hajlandó és képes adaptálni, akkor az olyan információkhoz juthat a saját gazdaságáról, amely a hosszútávon a tervezhető megélhetését biztosítja.

\section{IRODALOMJEGYZÉK}

[1.] Algeier W. (2013): A kertészet meghatározó szakágazat. Kertészet és szőlészet. No. 62. Vol. pp. 41.25

[2.] Czene Zs. - Ritz J. szerk. (2010): Ötletadó megoldások, jó gyakorlatok. Területfejlesztési füzetek. NFM-NGM-VÁTI, Budapest, 192 p.

[3.] Ferencz Á. (2006): A vidék fejlesztésének munkaszervezési és ökonómiai összefüggései. In.

[4.] A térségfejlesztés vezetési és szervezési összefüggései, Ünnepi könyv, Szerk: Jávor A.-

[5.] Berde Cs., Debreceni Egyetem ATC Debrecen, pp. 121-136 
[6.] Ferencz Á. -Marselek S. (2007): Üzemtan in Növénytermesztés és kertészet szervezése és ökonómiája. Zöldségtermesztés. Szerk. Nábrádi A., Debreceni Egyetem, Agrártudományi Centrum. pp. 210-225

[7.] Ferencz Á. -Nótári M. (2007): Economic evaluation in the programs of rular development in Hungary. Anals of the Faculty of Engineering Hunedora. No.6. Vol 1. pp. 83-87

[8.] Nábrádi A.-Pupos t.-Takácsné Gy. K (2008): Üzemtan II. Szaktudás Kiadó, Budapest

[9.] Vlahović, B. (2013): Survey results. Faculty of Agriculture, Novi Sad, kézirat, pp. 1-32 